Article Type: Research Paper

\title{
Analisis Pendapatan Usahatani Tebu di Kecamatan Bunga Mayang Kabupaten Lampung Utara Provinsi Lampung
}

\author{
Fajar Iman Santoso ${ }^{1}$, dan Dyah Titis Kusuma Wardani ${ }^{1}$
}

\begin{abstract}
Abstrak: Penelitian ini bertujuan untuk menganalisis pendapatan petani tebu di Kecamatan Bunga Mayang. Objek penelitian ini adalah petani tebu di Kecamatan Bunga Mayang. Dalam penelitian ini, peneliti mengambil sampel berjumlah 94 responden petani yang dipilih menggunakan rumus slovin. Alat analisis yang digunakan adalah analisis regresi linier berganda. Berdasarkan analisis hasil yang diperoleh dalam penelitian ini bahwa modal, harga, luas lahan, jumlah produksi, dan biaya produksi berpengaruh signifikan terhadap pendapatan petani tebu. Dengan pertambahan lahan tanam pohon tebu petani maka produksi yang dihasilkan akan semakin melimpah, untuk mendapatkan keuntungan yang besar biaya produksi yang dikeluarkan harus seminimal mungkin, tetapi diimbangi dengan harga gula yang stabil naik. Penggunaan modal usaha untuk pembelian peralatan dan juga pembelian pupuk yang dapat meningkatkan jumlah produksi sangat dibutuhkan bagi petani.

Kata Kunci: Pendapatan; Modal; Harga; Luas Lahan; Biaya Produksi; Jumlah Produksi.
\end{abstract}

SITASI:

Santoso, F. I., \& Wardani, D. T. K. (2020). Analisis Pendapatan Usahatani Tebu di Kecamatan Bunga Mayang Kabupaten Lampung Utara Provinsi Lampung. Journal of Economics Research and Social Sciences, 4(1), 103-109.

\section{Pendahuluan}

Indonesia dikenal oleh dunia sebagai negara agraris dan gula merupakan salah satu komoditas perkebunan yang memiliki nilai ekonomis yang cukup tinggi. Gula menjadi salah satu komoditas strategis dalam perekonomian Indonesia dengan luas areal sekitar 350 ribu hektar pada periode tahun 2000-2005, usahatani berbasis tebu menjadi salah satu sumber pendapatan bagi sekitar 900 ribu petani (Susila, 2005). Jika dilihat dari data tersebut, usahatani tebu sangat penting bagi terciptanya lapangan kerja terutama bagi para petani gula di seluruh Indonesia. Usahatani adalah kegiatan mengorganisasikan atau mengelola aset dan cara dalam pertanian. Usahatani juga dapat diartikan sebagai suatu kegiatan yang mengorganisasi sarana produksi pertanian dan teknologi dalam suatu usaha yang menyangkut bidang pertanian (Daniel, 2001).

Maksimalisasi keuntungan atau pendapatan merupakan tujuan utama petani dalam melakukan kegiatan produksi tebunya. Berdasarkan penelitian terdahulu terhadap usahatani, pendapatan petani dipengaruhi secara langsung oleh jumlah produksi, harga jual, luas lahan dan biaya produksi (Triyanti, 2017). Berdasarkan hal tersebut petani sangat mengharapkan hasil produksi tebu yang maksimal dari setiap hasil panennya agar mendapatkan laba atau keuntungan yang juga maksimal 
melebihi dari biaya produksi selama para petani melakukan kegiatan produksi. Menurut Rasahan (1989), ia menyimpulkan bahwa biaya produksi sangat mempengaruhi pendapatan petani. Jika dapat menekan biaya produksi, maka pendapatan yang didapat petani akan semakin banyak. Dengan hasil yang maksimal tersebut, petani dapat mengalokasikan dananya untuk modal selanjutnya dan untuk biaya hidup sehari-hari.

Kecamatan Bunga Mayang menjadi daerah terbesar penghasil komoditas tebu rakyat di antara 5 kecamatan yang ada di Kabupaten Lampung Utara. Pada tahun 2015 dan 2016, luas lahan Kecamatan Bunga Mayang mencapai 2.324 ha dan 2.070 ha lahan sedangkan hasil produksinya sebesar 12.561 ton pada tahun 2015 dan 8.483 pada tahun 2016 . Berdasarkan fakta tersebut Kecamatan Bunga Mayang merupakan daerah yang sangat potensial untuk dijadikan daerah andalan penghasil komoditas tebu rakyat di Kabupaten Lampung Utara.

Tinggi rendahnya pendapatan petani tebu dapat dipengaruhi dari berbagai macam faktor. Dalam penelitian kali ini yang berlokasi di Kecamatan Bunga Mayang beberapa faktor akan diteliti untuk mengetahui seberapa besar faktor-faktor tersebut mempengaruhi pendapatan yang diperoleh petani. Faktor-faktor tersebut antara lain jumlah luas lahan usahatani yang di miliki petani, modal usahatani yang harus dikeluarkan petani untuk pembelian bibit, peralatan selama produksi, pupuk dan lainlain, biaya produksi seperti biaya perawatan tanaman tebu, upah tenaga kerja hingga panen, harga jual komoditas tebu yang ada di pasaran dan jumlah produksi yang dihasilkan petani tebu merupakan beberapa faktor yang dapat mempengaruhi besar kecilnya pendapatan yang diperoleh petani.

\section{Tinjauan Pustaka}

Dalam penelitian Yanutya (2013), dengan menggunakan analisis linier berganda, ia mendapatkan bahwa luas lahan, biaya tenaga kerja serta umur tidak memiliki pengaruh yang signifikan terhadap pendapatan petani. Sedangkan, modal, Pendidikan dan harga berpengaruh secara signifikan terhadap pendapatan petani. Dengan menggunakan alat analisis yang sama, Zhang dan Lou (2015) menemukan bahwa luas lahan, konsumsi pupuk, investasi nasional, tenaga kerja serta Pendidikan secara bersama-sama berpengaruh terhadap pendapatan petani karet. Windi (2017) juga menyimpulkan bahwa secara parsial faktor seperti benih, obat-obatan dan luas lahan berpengaruh signifikan terhadap pendapatan usahatani kedelai. Sementara pupuk dan tenaga kerja tidak berpengaruh secara signifikan terhadap pendapatan usahatani kedelai.

Dengan menggunakan metode yang berbeda, Lumintang (2013) mengatakan bahwa besar kecilnya pendapatan usahatani padi sawah yang diterima oleh penduduk di desa di pengaruhi oleh penerimaan dan biaya produksi. Jika produksi dan harga jual padi sawah semakin tinggi maka akan meningkatkan penerimaan. Mawardati (2013) juga menyimpulkan bahwa variabel produksi dan harga berpengaruh sangat signifikan terhadap pendapatan. Variabel modal tidak signifikan mempengaruhi pendapatan karena petani pinang sangat sedikit menggunakan modal dalam kegiatan usahataninya. 


\section{Metode Penelitian}

Penelitian ini bertujuan untuk mengetahui faktor-faktor yang mempengaruhi pendapatan usahatani tebu di Kecamatan Bunga Mayang Kabupaten Lampung Utara. Pada penelitian ini jenis data yang digunakan berdasarkan sumber data yang diperoleh, yaitu data primer. Data primer didapatkan secara langsung melalui observasi dan wawancara dengan responden.

Adapun dalam menentukan jumlah sampel peneliti menggunakan metode Slovin untuk menghitung jumlah sampel yang diperlukan. Berdasarkan jumlah populasi petani, maka diperoleh jumlah sampel yang digunakan sebagai responden oleh peneliti yang dihitung menggunakan metode slovin dengan tingkat signifikansi 10\% adalah 94 responden.

\section{Hasil dan Pembahasan}

Tabel 1 Hasil Uji Normalitas Data

\begin{tabular}{ll} 
& Unstandarized Residual \\
\hline Kolmogorov-Smirnov & 1.326 \\
Asymp.Sig. (2-tailed) & .060 \\
\hline
\end{tabular}

Sumber: Data diolah

Berdasarkan hasil uji normalitas dengan uji One-Sample Kolmogorov-Smirnov Test Z, hasilnya menunjukkan bahwa nilai Asyimp. Sig. (2-tailed) sebesar 0,60>0,05. Sehingga dapat disimpulkan bahwa data berdistribusi normal.

Sedangkan untuk mengetahui adanya multikolinearitas dapat dilihat dengan nilai dari Variance Inflation Factor (VIF) dan Tolerance. Untuk mengetahui bebas dari multikolinearitas adalah jika nilai VIF $<10$ dan nilai toleransi $>0,1$ maka tidak ada hungan korelasi antara variabel independen dinyatakan bebas multikolinearitas.

Tabel 2 Hasil Uji Multikolinearitas

\begin{tabular}{llll}
\hline Variabel Independen & Toleransi & VIF & Kesimpulan \\
\hline Modal & .940 & 1.064 & Non Multikolinearitas \\
LuasLahan & .572 & 1.749 & Non Multikolinearitas \\
BiayaProduksi & .425 & 2.355 & Non Multikolinearitas \\
Harga & .963 & 1.039 & Non Multikolinearitas \\
JumlahProduksi & .345 & 2.897 & Non Multikolinearitas \\
\hline
\end{tabular}

Sumber: Data primer yang diolah dengan SPSS 21.0, 2019

Berdasarkan hasil uji multikolinearitas, didapatkan hasil bahwa nilai VIF variabel modal, harga, luas lahan, biaya produksi, jumlah produksi kurang dari 10 dan nilai Toleransinya lebih dari 0,1. Sehingga dapat diambil kesimpulan bahwa dalam model regresi penelitian ini tidak ada multikolinearitas antar variabel independen. 
Untuk mengetahui ada tidaknya heteroskedastisitas penelitian ini yaitu dengan menggunakan metode Glesjer. Uji Glesjer dilakukan dengan menggunakan nilai absolut residual. Residual adalah selisih antara nilai observasi dan nilai prediksi. Untuk melihat adanya heteroskedastisitas adalah dengan melihat nilai signifikan dari tabel koefisien jika nilai signifikan lebih besar dari 0,05 maka dapat disimpulkan bahwa tidak ada heteroskedastisitas antara variabel independen terhadap nilai absolut residual.

Tabel 3 Hasil Uji Heteroskedastisitas

\begin{tabular}{|c|c|c|c|c|c|c|}
\hline \multirow{2}{*}{\multicolumn{2}{|c|}{ Model }} & \multicolumn{2}{|c|}{ Unstandardezed Coeficients } & \multirow{2}{*}{$\begin{array}{l}\text { Standardized Coeficients } \\
\text { Beta }\end{array}$} & \multirow[t]{2}{*}{$T$} & \multirow[t]{2}{*}{ Sig. } \\
\hline & & B & Std. Error & & & \\
\hline \multirow[t]{6}{*}{1} & (Constan) & 98.531 & 53.973 & & & \\
\hline & LnModal & .101 & .459 & .023 & .221 & .826 \\
\hline & LnLuas_Lahan & .039 & .053 & .101 & .743 & .460 \\
\hline & LnBiaya_Produksi & .127 & .073 & .275 & 1.747 & .084 \\
\hline & LnHarga & -11.038 & 5.969 & -.193 & -1.849 & .068 \\
\hline & LnJumlah_Produksi & -.133 & .081 & -.288 & -1.649 & .103 \\
\hline
\end{tabular}

Sumber: Data primer yang diolah dengan SPSS 21.0, 2019

Dapat dilihat bahwa nilai signifikansi seluruh variabel independen lebih besar dari 0,05. Dapat disimpulkan bahwa tidak terjadi hubungan signifikansi antara variabel independen dengan nilai absolut residual maka dalam penelitian ini tidak ada heteroskedastisitas.

Guna membuktikan hipotesis pada penelitian ini, pengujian perlu dilanjutkan ke tahap selanjutnya, yaitu regresi linier berganda.

Tabel 4 Hasil Regresi Linier Berganda

\begin{tabular}{lllll}
\hline Variabel & B & T Hitung & Sig. & Kesimpulan \\
\hline Intercept & $-235,622$ & $-2,638$ & 0,010 & \\
LnModal & 3,363 & 4,426 & 0,000 & Signifikan \\
\hline LnLuasLahan & 0,181 & 2,072 & 0,041 & Signifikan \\
\hline LnBiayaProduksi & $-0,271$ & $-2,248$ & 0,027 & Signifikan \\
\hline LnHarga & 20,895 & 2,116 & 0,037 & Signifikan \\
LnJumlahProduksi & 1,042 & 7,794 & 0,000 & Signifikan \\
F Hitung & 41.649 & & & \\
Sig. F & 0,000 & & & \\
R Square & 0,703 & & & \\
Adjusted R Square & 0,686 & & & \\
\hline Pendapatan Petani Tebu (Y) & Variabel dependen & & \\
\hline Sumber: Data diolah & & & & \\
\hline
\end{tabular}

Sumber: Data diolah

Berdasarkan hasil dari regresi didapatkan bahwa nilai t-hitung variabel harga sebesar 4,426. dengan nilai signifikansi adalah $0.000<0,05$ maka $H_{0}$ ditolak. Hasil ini menunjukkan bahwa variabel modal (M) memiliki pengaruh yang signifikan terhadap variabel dependen yaitu pendapatan petani $(P)$. Penelitian ini berlawanan dengan hasil penelitian yang telah dilakukan oleh Mawardati (2013) yang menyatakan bahwa modal tidak berpengaruh signifikan terhadap pendapatan petani. Tidak signifikannya variabel modal dalam penelitiannya karena petani dalam penelitiannya sebagian besar tidak 
menggunakan pupuk dan obat pembasmi hama yang dapat meningkatkan hasil produksi.

Berdasarkan hasil dari regresi didapatkan bahwa nilai t-hitung variabel luas lahan sebesar 2,072. Dengan nilai signifikansi adalah $0.041<0,05$ maka $\mathrm{H}_{0}$ ditolak. Hasil ini menunjukkan bahwa variabel luas lahan (LL) memiliki pengaruh yang signifikan terhadap variabel dependen yaitu pendapatan tani (P). Penelitian ini sejalan dengan penelitian yang telah dilakukan oleh Triyanti (2017) dan Suryatiningtias (2018) yang menyatakan luas lahan dapat mempengaruhi pendapatan yang diperoleh petani dengan alasan semakin besar lahan yang di miliki petani akan semakin banyak tanaman yang dapat ditanam yang dapat meningkatkan hasil produksi petani untuk dapat dijual.

Variabel berikutnya yakni biaya produksi, dengan nilai t-hitung sebesar $-2,248$. Dengan nilai signifikansi adalah 0,027<0,05 maka $\mathrm{H}_{0}$. Hasil ini menunjukkan bahwa variabel biaya produksi (BP) memiliki pengaruh yang signifikan terhadap variabel dependen yaitu pendapatan petani (P). Penelitian ini sejalan dengan penelitian yang telah di lakukan oleh Triyanti (2017) dan Suryatiningtias (2018) yang menyatakan bahwa biaya produksi dapat mempengaruhi pendapatan yang diperoleh petani dengan alasan semakin besar biaya produksi yang harus dikeluarkan petani maka hal itu akan mengurangi pendapatan yang di dapat petani. Jika ingin meningkatkan pendapatannya maka petani harus dapat menekan biaya produksi selama melakukan proses produksi.

Berdasarkan hasil regresi didapatkan bahwa nilai t-hitung variabel harga $(\mathrm{H})$ adalah sebesar 2,116. Dengan nilai signifikansi adalah 0,037<0,05 maka $\mathrm{H}_{0}$ ditolak. Hasil ini menunjukkan bahwa variabel harga $(H)$ memiliki pengaruh yang signifikan terhadap variabel dependen yaitu pendapatan petani $(\mathrm{P})$. Penelitian ini sejalan dengan penelitian yang telah dilakukan oleh Triyanti (2017) dan Mawardati (2013) yang menyatakan bahwa harga jual dapat mempengaruhi pendapatan yang diperoleh petani dengan alasan semakin tinggi harga jual maka akan semakin tinggi pendapatan yang diperoleh petani.

Berdasarkan hasil regresi didapatkan bahwa nilai t-hitung variabel jumlah produksi (JP) adalah sebesar 7,794. Dengan nilai signifikansi adalah $0,000<0,05$ maka $\mathrm{H}_{0}$ ditolak. Hasil ini menunjukkan bahwa variabel jumlah produksi (JP) memiliki pengaruh yang signifikan terhadap variabel dependen yaitu pendapatan petani $(P)$. Penelitian ini sejalan dengan penelitian yang telah dilakukan oleh Triyanti (2017) tentang komoditas karet yang menyatakan bahwa jumlah produksi dapat mempengaruhi pendapatan yang diperoleh petani. dengan alasan semakin banyak jumlah produksi yang dihasilkan maka akan semakin banyak hasil produksi yang dapat dijual dan tentunya akan meningkatkan pendapatan petani.

Mengacu pada Uji F, diketahui bahwa nilai signifikan sebesar 0,000. Dengan menggunakan tingkat kepercayaan $(\alpha)=0,05$, maka nilai signifikan penelitian ini $0,000<$ 0,05 . Maka dapat disimpulkan bahwa variabel independen modal, luas lahan, biaya produksi, harga dan jumlah produksi secara bersama-sama memiliki pengaruh terhadap 
variabel dependen yaitu pendapatan petani tebu dalam penelitian ini. Selanjutnya pengujian koefisien determinasi perlu untuk dilakukan.

Tabel 5 Hasil Uji Koefisiensi Determinasi $\left(R^{2}\right)$

t Model Summary ${ }^{b}$

\begin{tabular}{lllll}
\hline Model & $\mathbf{R}$ & $\mathbf{R}$ Square & Adjusted $\mathbf{R}$ Square & Std. Error of the Estimate \\
\hline $\mathbf{1}$ & 0.838 & 0.703 & 0.686 & 0.41834 \\
\hline
\end{tabular}

Sumber : Data diolah

Dari tabel 5 bahwa nilai adjusted $\mathrm{R}^{2}$ dalam penelitian ini sebesar 0,686. Maka, ini berarti bahwa variabel independen dalam penelitian ini yaitu modal (M), luas lahan (LL), biaya produksi $(\mathrm{BP})$, harga $(\mathrm{H})$ dan jumlah produksi (JP) mampu menjelaskan variabel dependen pendapatan petani karet $(Y)$ sebesar 68,6 persen. Sehingga sisanya 31,4 persen di jelaskan oleh variabel lain dil uar model penelitian ini.

\section{Kesimpulan}

Berdasarkan hasil dari penelitian yang dilakukan pada usahatani tebu di Kecamatan Bunga Mayang Kabupaten Lampung Utara, dapat ditarik kesimpulan sebagai berikut. Variabel modal, luas lahan, harga, dan jumlah produksi memiliki pengaruh positif dan signifikan terhadap jumlah pendapatan yang diterima petani. Sedangkan, biaya produksi secara signifikan berpengaruh negative terhadap pendapatan yang diterima oleh petani.

Penulis juga memberikan saran kepada para pemangku kebijakan untuk lebih memperhatikan nasib petani. Pemerintah diharapkan dapat meningkatkan harga jual gula agar pendapatan yang diperoleh petani lebih besar mengingat begitu besarnya biaya produksi yang harus dikeluarkan petani selama melakukan proses produksi. Sosialisasi bagi petani untuk meningkatkan kualitas produksi tebunya yang saat ini di Kecamatan Bunga Mayang sangatlah diperlukan. Selain itu, pemerintah sebaiknya lebih bijak dalam melakukan kebijakan impor gula dari negara lain. Jangan sampai hasil produksi gula petani lokal kalah bersaing dengan gula yang diimpor dari negara lain.

\section{Daftar Pustaka}

Daniel, M. (2001). Pengantar Ekonomi Pertanian. Bumi Aksara: Jakarta.

Lumintang, F. M. (2013). Analisis Pendapatan Petani Padi di Desa Teep Kecamatan

Lawongan Timur. Jurnal Emba, 1(3), 991-998.

https://doi.org/10.35794/emba.v1i3.2304

Mawardati.(2013). Analisis Faktor-faktor Yang Mempengaruhi Pendapatan Usahatani Kentang. Jurnal Agrium, 10(2), 38-42.

Rasahan, C.A. (1988). Perspektif Struktur Pendapatan Masyarakat Pedesaan dalam Hubungannya dengan Kebijaksanaan Pembangunan Pertanian dalam Kasryno, et al (Penyunting) Prosiding Patanas: Perubahan Ekonomi Pedesaan Menuju 20 Struktur Ekonomi Berimbang. Pusat Penelitian Agro Ekonomi, Badan Litbang Pertanian. 
Suryatiningtias. (2018). Faktor-faktor yang mempengaruhi pendapatan petani karet Kecamatan Pakuan Ratu Kabupaten Way Kanan Prov. Lampung. Skripsi. Universitas Muhammadiyah Yogyakarta.

Susila, W. R. (2005). Pengembangan Industri Gula Indonesia: Analisis Kebijakan danKeterpaduan Sistem Produksi. Disertasi Doktor. Institut Pertanian Bogor.

Triyanti, N. (2017). Analisis Pendapatan Usahatani Karet Kabupaten Musi Rawas Provinsi Sumatera Selatan. Skripsi: Universitas Muhammadiyah Yogyakarta.

Windi, M. T. (2017). Analisis Pendapatan Usahatani Kedelai di Kecamatan Berbak Kabupaten Tanjung Jabar Timur. Skripsi. Universitas Jambi.

Yanutya. P. A. T. (2013). Analisis Pendapatan Petani Tebu di Kecamatan Jepon Kabupaten Blora. Economics Development Analysis Journal 2(4), 286-296. https://doi.org/10.15294/edaj.v2i4.2504

Zhang, D., \& Lou, S. (2015). Farmers' Income Structure in Heilongjiang Province. Proceedings on the Second International Conference on Civil, Materials, and Environmental Sciences. https://dx.doi.org/10.2991/cmes-15.2015.151 